\title{
ЕДУКАТИВНИ ПОТЕНЦИЈАЛ МУЗЕЈА САВРЕМЕНЕ УМЕТНОСТИ ВОЈВОДИНЕ
}

\begin{abstract}
Апстракт
Рад се фокусира на нужност континуираног педагошког рада и оснивање едукативног центра за све узрасте у оквиру музеја савремене уметности који данас у свету имају значајан статус за развој градова у којима се налазе. С обзиром на то да савремена уметност није део школских програма, како је то случај са историјом, природом и техником, музеји савремене уметности су места где она треба да је приступачна и разумљива посетиоцима свих узраста. Рад даје приказ педагошких пракси одабраног броја музеја савремене уметности у свету, затим анализира рад са посетиоцима у Музеју савремене уметности Војводине (МСУВ) у периоду од 2012. до 2015. и коначно даје предлоге за побољшање овог сегмента рада Музеја, имајући у виду значај који ова институција има за промовисање савремене уметности у Србији.
\end{abstract}

Кључне речи: музеј, савремена уметност, посетиоци, МСУВ.

\section{EDUCATIONAL POTENTIONAL OF THE MUSEUM OF CONTEMPORARY ART VOJVODINA}

\begin{abstract}
The paper focuses on the necessity of continuous pedagogical work and the establishment of an educational center for all ages as part of the museum of contemporary art, that has a significant status for the development of the city in which it is located. Given the fact that contemporary art is not a part of the school curriculum, as it is the case with history, nature and technology, contemporary art museums are places that need to be accessible and understandable to visitors of all ages. The
\end{abstract}


paper presents pedagogical practices of a selected number of museums of contemporary art in the world, then analyses the work with visitors in the Museum of Contemporary Art of Vovodina (MCAV) in the period from 2012 to 2015. Finally, the paper gives suggestions for improving this segment of the Museum, bearing in mind the importance of this institution for promotion of contemporary art in Serbia.

Keywords: museum, contemorary art, visitors, MCAV.

\section{1. УВОД}

Савремена уметност није уско повезана са основношколским програмима, тако да музеји савремене уметности имају другачији приступ најмлађој публици него што то имају природњачки, историјски и технолошки музеји. Садржаји и програми музеја савремене уметности су у потпуности страни ученицима, али и публици средње и старије доби, тако да музеји савремене уметности имају другачији, па чак и интензивнији, приступ маркетиншком и педагошком раду како би привукли публику. Док код нас постоје музеји чија је делатност генерално оријентисана на савремену уметност, у свету постоје специјализовани музеји за само одређене видове савремене уметности, тако да постоје музеји интерактивне уметности, музеји инсталација у отвореном простору (који имају огранке за инсталације од природних или синтетичких материјала), музеји светлосних инсталација и читавог низа медија и сфера уметности са којима просечни грађанин није имао прилике да се сусретне на другим местима у животу. За разлику од њих, музеји савремене уметности у ширем значењу често се не ограничавају само на савремену уметност, тако да у њиховим програмима налазимо и радове из хуманистике. Социологија уметности, студије култуpe, историја уметности, студије музеја, net.art, био-арт, еко-арт, техно-арт, уметност машина, in situ инсталације, визуелна психо-географија, уметност базе података, уметност која се у сагласју са теоријом и критиком фокусира на архитектуру и урбанизам, перформанс, интерактивна уметност - само су неке од области које музеји савремене уметности адресирају. Управо због тога је педагошка служба обавезан и изразито важан сегмент музеја савремене уметности.

Овим радом даје се приказ нових тенденција рада музеја савремене уметности у свету, затим педагошких метода које се примењују у Музеју савремене уметности Војводине (МСУВ) и оних које се могу реализовати у будућности, истичући важност оснивања едукативног центра који би 
задовољио потребе публике свих старосних доби. Савремена уметност је у великој мери страна и одраслим људима јер су управо музеји савремене уметности места на којима посетиоци имају прилику да виде неке сасвим нове тенденције у свету које никада нису раније виђене у градовима и државама у којима живе. Из тог разлога рад се фокусира на методе стварања нове публике и методе рада са њом, кроз групна и индивидуална вођења, интерактивне презентације, пројекције, анимације, дискусије, могућност темпоралног тематског парка, android/web апликација које упућују на то како доћи до Музеја, аудио-визуелне прилоге о колекцији, у складу са могућностима Музеја савремене уметности Војводине у домену технологије и особља.

\section{2. ТРЕНДОВИ У РАДУ МУЗЕЈА САВРЕМЕНЕ УМЕТНОСТИ У СВЕТУ}

На крају XX и почетку XXI века, музеј савремене уметности је „најрепрезентативнија зграда“ (Смит 2013: 248), „омиљено средство урбане регенерације и планова обнове“ (Фрејзер 2013: 233) које одговара одређеном профилу публике, циљном тржишту и циљном економском сектору. Током 2001. године било је 84 текућа пројекта изградње уметничких музеја у свету, што је очит показатељ индустријализације културе.

У тридесет случајева у питању је проширење или темељно реновирање, док се преостала 54 случаја односе на савим нове музеје или нове грађевине у близини већ постојећих. [...] Цене се крећу од 3,5 милиона долара за Палату Токио - реновиран део Музеја модерне уметности у Паризу, којим је овај простор претворен у мешавину места за техно-журке и центра за савремену уметност - до износа од 650 милиона долара (планирано за проширење Музеја модерне уметности у Њујорку) што све није ни близу 1,2 милијарде долара колико је потрошено за музеј Гети, довршен 1997. године. (Смит 2013: 246).

Паоло Балмас, при креирању мапе музеја савремене уметности у свету, такође ставља акценат на архитектонски аспект музеја, где се зграде, то јест архитектонски пројекти за музеје савремене уметности, третирају као „најрепрезентативнија дела саме савремене уметности“ (2010: 187).

Адаптација дела Палате Токио у место за техно-журке најпрецизније илуструје прелаз музеја из образовних институција у места забаве и бизниса у опуштеној атмосфери која привлачи публику колико и уметнике и донаторе. Према Јелени Стојановић, „отварање једног од првих музеја мо- 
дерне уметности 1929. године, у тренутку краха њујоршке берзе, односно развој све већег броја музеја савремене уметности од почетка хладног рата до данас, не проблематизује разлику између музеја и трговачког вашара, напротив" (2013: 14). Спектакуларизација музеја очитава се у њиховим трансформацијама од јавних образовних институција у корпоративне забављачке комплексе, а репрезент овог процеса је глобални Гугенхајмов музеј чији је најрепрезентативнији огранак у шпанском граду Билбау. Пословни план Гугенхајмових колекција створио је шему објеката на глобалном нивоу, нудећи, као и Мекдоналдс, проверену и очекивану робу/услугу у свим деловима света. Са друге стране, у настојању популаризације својих поставки за што већи број посетилаца, музеји, укључујући и оне у Србији, уводе забаван део у вечерње програме и отварања изложби, попут DJ журки.

Музеји су постали места опште спектакуларизације културе, потребе да баш све (историја, државна управа, градови, нови филмови, културно наслеђе, природни феномени, истакнуте јавне и приватне функције, чак и сами медији) буде претворено у атракцију, то јест, место-догађај. (Смит 2013: 245).

Овакав опис музеја далеко је од државне политике која међу програмима музеја - било да су они национални, регионални, градски или приватни - приоритет даје њиховој едукативној улози.

Музеј савремене уметности Војводине је угостио изложбе које су резултат интердисциплинарних истраживачких пројеката и приредио је тематске изложбе о социјално-историјско-културолошким контекстима савремене уметности (нпр. интернационална изложба Меморија насиља u снови о будућности 1914/1918-2014, која је организована поводом стогодишњице од Првог светског рата, дајући многе актуелне погледе на географско-културални контекст историјских догађаја). Насупрот униформисаним, глобализујућим музејима савремене уметности у свету, попут Гугенхајмове колекције, постоје музеји савремене уметности који су по нечему јединствени, што ствара нову публику. Јединственост Музеја савремене уметности Војводине је управо у оном сегменту који даје одговор на питање „савремена уметност са - чим?“ јер се кроз радове уметника који су заступљени у Музеју сазнаје како о новим светским тенденцијама, тако и о политичким, социјалним и културним појавама пост-југословенског периода. 
Савремена уметност се од краја шездесетих година XX века ослобађа двоструких стега музеја и тржишта и укључује се у политичке борбе свога времена. Са друге стране, музеји су тада били у највећем броју случајева музеји модерне уметности, евентуално музеји модерне и савремене уметности, при чему су се маргиналне појаве у модерној уметности тада сматрале савременом уметношћу. Данашњи музеји савремене уметности могу да се својим програмима, као и сама савремена уметност, укључе у политичке борбе свога времена, у разумевање разлика и оних политичких појава као што су род (gender), неолиберално економско и културно уређење, стране и мањинске културе, социјална права и сл. Управо је ово едукативна улога музеја савремене уметности јер „музеји активно помажу човеку да постане грађанин света, да разуме разлике, прихвати противречности, упозна новине, да се за часак нађе на другом крају света и доживи илузију сопственог присуства у њему“ (Суботић 2005: 12). Музеји учествују у изградњи свести о различитим вредностима и то управо кроз интерактивне поставке које захтевају укључивање публике - не само у поставке, већ у све оне социјалне проблематике које уметници и кустоси адресирају. Према Ирини Суботић:

ниво знања посетилаца музеја се не подразумева већ се мора изграђивати и стварати. Музејима је намењена посебна улога - да својом дидактиком формирају не само нову публику, већ и образоване грађане у најширем смислу - коју са задовољством и поносом преузимају сви они који себе виде као релевантног чиниоца културе. (2005: 11).

Из наведеног разлога музеји савремене уметности, укључујући и онај у Новом Саду, морају имати добро осмишљен едукативни сегмент за сваку изложбу/пројекат који представљају.

\section{3. УЛОГА КУСТОСА-ПЕДАГОГА У МУЗЕЈИМА САВРЕМЕНЕ УМЕТНОСТИ}

Демократичан и јаван статус музеја их чини отвореним за свакога - за „локално становништво које треба стимулисати за улазак у музеј, незапослене и неписмене, стране туристе који само једном посете музеј” (Суботић 2005: 10). Поводом тога, музеји организују различите педагошке програме, стављајући у централни део своје делатности посетиоце колико и предмете које баштине. „Стручни рад у музејима подразумева извршавање његових просветно-педагошких, колико и научних задатака“ (Јовановић 
1994: 85). Према Николасу Пулу, глас посетиоца и спољних сарадника је од великог значаја:

морамо (кустоси) допустити другим људима да говоре, није довољно очекивати да нас слушају. То је изазов управо због тога што је реч о равнотежи. Основа онога што радимо почива на ауторитету и знању, и то мора да буде заштићено и цењено, али, поред ауторитативног гласа музеја, морамо дати место за кориснике, аматере, спољне стручњаке. (Пул 2012: 8).

Због различитог степена знања о савременој уметности који различити посетиоци поседују, понуда музеја савремене уметности је изузетно широка, чак и када су специјализовани на само неке видове савремене уметности. Тако Charles M. Schulz Museum (музеј цртача стрипова о Снупију) у Калифорнији има богату понуду за најмлађе посетиоце који су циљна група Музеја. Педагошка, програмска и структурална понуда тог музеја укључује и вртиће у склопу тематског парка са балонима-скулптурама ликова из стрипа које су у људској величини. Географска позиционираност Музеја је веома повољна, на само неколико сати вожње од великих градова, те је викенд посета најпримеренија за обилазак. Када посетиоци већ дођу преко викенда, имају широку понуду програма који обухватају луткарске представе, пројекције, анимације, вођења кроз сталну поставку и привремене изложбе, активности у кампу, предавања у специјализованим учионицама за ђаке свих узраста, радионице стрипа. Поред тога, посетиоци могу купити некакав сувенир из музејске сувенирнице како би имали опипљив, материјални подсетник на све оно што су видели и научили у Музеју и лепо време које су тамо провели. Како је збирка у потпуности дигитализована и широко промовисана у електронским медијима и на социјалним мрежама, посетиоци долазе управо због јединственог и непоновљивог доживљаја амбијента, сусрета са оригиналним радовима - цртежима и због учешћа у интерактивним едукативним програмима. Старијим посетиоцима су на располагању вођења (основно вођење, дан у животу Чарлса Шулца, вођење директора), као и истраживачки центар. За реализацију свега наведеног су потребни кустоси-педагози који публици приближавају садржаје стрипова, историјске контексте у којима су настајали, форму стрипа као медија комуникације и живот Чарлса Шулца.

У домену едукације, Музеј савремене уметности у Стокхолму увео је неформалне туре за различите типове посета и различите циљне групе, како би се што више изашло у сусрет индивидуалним посетиоцима, тако 
да постоје вођења за „оне који журе, за оне који не виде ништа у модерној уметности и мисле да су и само то могли да насликају, за кишни дан итд." (Панић 2011: 32). Поред тога, постоје специјализоване туре за слепе и слобовиде, за људе са оштећеним слухом, за „родитеље са децом од 0 до 15 месеци, радионице са бебама (боровнице, јогурт и други јестиви производи се користе уместо боја), радионице за пензионере (Art History Salons, у којима уз чај дискутују са кустосима), радионице за адолесценте" (Панић 2011: 33). Одељење за едукацију Витни музеја америчке уметности у Њујорку има мали број запослених (свега четрнаест њих), али упркос томе спроводи „неколико типова едукативних програма: Отворени програм, Програм за грађане старијег доба, Програм за децу, Програм за школе, омладину и породицу, Програм директног рада са наставницима и професорима, оплајн едукацију, аудио-водиче и Кустоски програм“ (Поповић 2011: 22). Генерално, сви музеји, не само музеји савремене уметности, све више уводе интерактивно учешће посетилаца како би се на занимљив и забаван начин обезбедила трајност знања и створила код посетилаца потреба да постану стални учесници културних програма. Како би програми били прилагођени свим узрастима и како би интерактивну технику могли да корсите сви посетиоци, од изузетног значаја је рад кустоса-педагога. Није искључено да посетиоци, уз учење о грађи изложеној у музеју, науче и како да рукују техником са којом нису имали прилике да раде (попут тач-скрин монитора) или да науче како функционишу интерактивне инсталације кроз које се представља грађа.

Према Аготи Лукач, кустоскињи у Музеју литературе у Будимпешти, пре неколико година у Мађарској је био видљив недостатак „нове политике оријентације ка посетиоцу - изложбе које позивају велики број посетилаца нису професионално добро утемљене. Са друге стране, окретање ка посетиоцима имало је и неке добре ефекте на политику музеја" (2012: 13). Како је целокупна делатност музеја у великој мери окренута публици, улога кустоса-педагога је незаобилазна у приближавању музејских програма најширем кругу посетилаца. На нивоу истраживачког рада, кустос-педагог истражује и израђује анализу интереса и потреба у вези са програмима и услугама музеја, те сарађује са службом за односе са јавношћу на маркетингу музеја. Самостални организациони ангажман кустоса-педагога обухвата организовање и постављање тематских и дидактичких изложби, као и предавања о савременој уметности, које је претходно предложио/ла Стручном савету и директору. Кустос-педагог организује предавања, радионице, стручна вођења, визуелно-ликовне трибине и групне посете у сврху популаризације савремене уметности и делатности Музеја, док у сарадњи 
са осталим кустосима учествује у изради музејског програма, каталога, проспеката и музејских публикација. Кустос-педагог, такође, сарађује са образовним и истраживачким институцијама, музејским друштвима, просветно-педагошким службама и невладиним организацијама, водећи евиденцију сарадње (у оквиру извештаја о раду). ${ }^{1}$

Поред тога, материјали из музејских фондова се временом реконтекстуализују, осавремењују, уз нове стратегије тумачења и у оквиру иновативних концепција излагања како би се познатим предметима дао сасвим нов приступ и тиме ново значење, или да би се приближили новим генерацијама којима нису познати из постојећих контекста. Улога кустосапедагога је значајна и у тој фази реконтекстуализације постојећих музејских колекција, поготово имајући у виду појаву нових обележја савременог живота попут глобализације, миграција услед привремених пословних уговора, интернета, Скајпа (Skype) и сл. које нису биле део живота просечног становника у времену када су те колекције почеле да се формирају. Све те појаве могу постојеће колекције савремене уметности чинити другачије видљивим и мање приступачним новим генерацијама.

\section{4. МСУВ: АКТИВНОСТИ И МОГУЋНОСТИ}

Музеј савремене уметности Војводине располаже са два галеријска простора, уз могућност коришћења још једног, затим кино-салом, док је у плану преуређење сутеренског дела испод прилазног платоа згради Музеја, чиме би се добио још један простор за излагање, презентације, дискусије и библиотеку. Ни у једном од постојећих или планираних изложбених простора се не налази стална поставка, док је мали део колекције приказан у дигиталној форми преко сајта Музеја. Афирмативан тон о колекцији и фонду Музеја на интернет-презентацији, уз информације о откупљеним уметничким радовима, наводи посетиоце да дођу у Музеј. Тек по уласку у Музеј види се да нема сталне поставке на којој би били изложени неки од откупљених и дарованих радова.

Недостатак сталне поставке МСУВ настоји да надомести богатим програмом који се одвија у његовим просторијама. МСУВ годишње продуцира или угости око 50 програма и улаз је бесплатан, уз поједине изузетке

1 Преузето из систематизације радних места Музеја сувремене умјетности у Загребу. Неке установе у Србији са музејско-галеријском делатношћу су такође начиниле јавно доступним систематизацију радних места унутар њих, попут Галерије ликовне уметности поклон збирке Рајка Мамузића. 
гостујућих концерата или фестивалских пројекција којима Музеј уступи простор за реализацију програма. Примера ради, током 2014. године, МСУВ је продуцирао или угостио 16 изложби, 2 семинара о менаџменту у култури, 3 филмска фестивала (Cinema City, Слободна зона и Shortz), фестивал видео-радова (ВидеоМедеја), 2 радионице (Вршњачка едукација и Лутајући отисак), конференцију (у организацији Завода за културу Војводине), трибину (у организацији колектива Герусија), Балкански компјутерски конгрес и форум о савременој уметности и култури, Фотомаратон, концерт Јозефа фон Вајсема (у организацији Кнап-а), 4 предавања, 5 промоција књига (издавачи: МСУВ, организација Напон, колектив Трећи Београд, Слободан Малдини, Завод за културу Војводине), уз презентације пројеката, радова група аутора, невладиних организација и јавних колекција савремене уметности. ${ }^{2}$ Многе од изложби обухватале су пратеће вечерње програме презентације, пројекције и разговоре, док је пропратни део сваке изложбе заказано јавно стручно вођење кустоса.

Од деветнаест стално запослених радника у Музеју савремене уметности Војводине, ${ }^{3}$ осам је кустоса збирки, укључујући и кустоса-саветника. Поред њих, ту је општа служба, два техничара, менаџер мултимедије, служба за односе са јавношћу, конзерватор, продуцент и дизајнер. На сталном располагању посетиоцима свих изложби не стоје запослени кустоси збирки јер је њихово радно време другачије од радног времена Музеја за посетиоце, нити постоје запослени кустос-педагог или водич, иако у систематизацији постоји предвиђено радно место. Тај посао обављају привремено ангажовани асистенти посетиоцима / дежуранти / водичи, уз ангажовање додатних дежураната током популарних и добро посећених манифестација, попут Ноћи музеја. Када уђе у зграду, посетилац прву информацију добија од портира од којих ниједан није радник МСУВ-а и који тиме нису редовно обавештени о дешавањима. Водич/дежурант је у Музеју савремене уметности Војводине на располагању посетиоцима свих узраста, степена образовања и студија, као и иностраним посетиоцима Музеја који желе да сазнају више о савременој уметности Војводине, историји Музеја или згради у којој се налазе изложбене просторије. Музеј настоји да у оквиру сваке изложбе организује стручно вођење кустоса или гостујућих стручњака, разговор са уметницима, презентације и додатне пројекције које нису свакодневно

2 Детаљан програм се може видети у Архиви изложби и догађаја у 2014. години на сајту Музеја савремене уметности Војводине.

3 Преглед је рађен 2015. године, док је у међувремену дошло до промене наведеног броја запослених. 
укључене у изложбу, док су у оквиру неких изложби организовани додатни едукативни мултимедијални програми. Тако је, на пример, реализована радионица о стварању видео-радова у оквиру изложбе Бреда Бебан: назовимо то љубав (у сарадњи са Културним центром Београда), радионица за ученике основних школа у оквиру изложбе савремене уметности Тајвана (у сарадњи са Удружењем грађана Трачак), радионица Camera Obscura одржана на Ноћ музеја 2013. године у оквиру изложбе Close-up \& Blow-up: ре-конструкиија фотографске слике (у сарадњи са Академијом уметности) итд.

Одређени едукативни програми су се спроводили конкурсно, попут изложбе студентских радова на тему стваралаштва Виктора Вазарелија и потом су радови који су победили на конкурсу били изложени током изложбе Вазарелијевих радова у Музеју почетком 2010. године. Што се тиче сарадње са високообразовним институцијама, МСУВ је 2014. започео сарадњу са Факултетом техничких наука, то јест са Катедрама за архитектуру и урбанизам, а поготово са Катедром за сценски дизајн, при чему се омогућава студентима да део праксе обаве у Музеју. У зависности од школских и студентских програма, у Музеју се понекад одвија и настава за студенте Академије уметности и Катедре за анимацију са Факултета техничких наука, као и за ученике стручних школа (Школа за дизајн „Богдан Шупут“, Техничка школа „Милева Марић“). Поменута предавања нису јавног карактера, мада су посетиоци који су тада у музеју добродошли. У сарадњи са другим институцијама и невладиним организацијама, у Музеју су организовани семинари из менаџмента у култури, техно-еколошке уметности и савремене музике.

Узимајући у обзир сва ограничења и могућности са којима располаже, МСУВ посвећује пажњу едукативном аспекту, што се може видети и на интернет-страници Музеја, где је садржана и архива одржаних радионица са ученицима основних и средњих школа. Највећи искорак у педагошком раду, МСУВ је направио у сарадњи са Удружењем грађана Студио Мано, увођењем програма „Едукација - програм за најмлађе“. Кроз овај програм савремена уметност се приближава деци прва четири разреда основних школа, радећи на развоју дечјег ликовног стваралаштва, кроз неговање и усавршавање креативног потенцијала деце. Едукација се реализује у договору са основним школама, у изложбеним просторима Музеја, како би најмлађи имали непосредан контакт са делима и тенденцијама савремене уметности. Сама едукација се врши у две фазе - прва је теоријска едукација у виду вођења кроз текућу изложбу од стране дежуранта/водича и активног разговора са децом о основним улогама музеја, о томе шта је савремена 
уметност и о одабраним радовима о којима се говори језиком разумљивим њиховом узрасту. Други део чине програми радионица који су флексибилни и креира их Студио Мано, прилагођавајући их изложбеном програму Музеја. Практична едукација подразумева стручну помоћ и подршку, кроз групни рад и потенцирање на новим техникама или креативном приступу познатим техникама ликовног изражавања како би деца упознала нове теме. Овај програм, у којем су присутни и наставници, омогућава деци доживљај, активност, нову животну ситуацију, повезаност теорије са праксом и трајност знања.

Како савремена уметност по себи није блиска наставним предметима у оквиру основношколског образовања, поменути програм обезбеђује пре свега процес социјализације деце у ваннаставној активности која се одвија у музејском окружењу, то јест окружењу које је другачије од школског, а опет мање захтевно од излета и екскурзија. Овакав вид едукације значајан је са свог интердисциплинарног аспекта - деца кроз цртање уче о екологији, о страним културама, о прошлости, о архитектури (са којом се, као са појмом, деца тог узраста тада први пут сусрећу). Деца имају прилику да кажу своја мишљења и идеје о темама које су покривене изложбама и радионицама. На тај начин, Музеј савремене уметности, чији се програм не може лако уклопити са наставним програмом како је то случај са историјским, природњачким и технолошким музејима, има значајну улогу у едукацији деце и то управо у домену социјализације и упознавања са друштвеним животом околине у којој живе. Управо у том сегменту је МСУВ близак раду дечјих музеја, „схваћеним као играонице за развијање вештина и знања која су запостављена основним образовањем” (Суботић 2005: 24) јер деца тада не раде само са својим учитељима и наставницима, већ и са запосленима у Музеју. Приликом обиласка изложби, деца имају прилику да уче док су и други посетиоци у музеју, што се не дешава у учионицама. У оквиру програма МСУВ „Едукација - програм за најмлађе“, деца активно учествују кроз дијалоге и ликовни рад, дајући и своје предлоге и развијајући тиме сопствено искуство истраживачког рада.

\section{5. ПРЕДЛОЗИ ЗА БУДУЋЕ ПРОГРАМЕ ЕДУКАЦИЈЕ У МУЗЕЈУ САВРЕМЕНЕ УМЕТНОСТИ ВОЈВОДИНЕ}

Музеј савремене уметности Војводине је активан на два нивоа - физичком, у форми текућих изложби у постојећим изложбеним просторима и виртуелном, преко интернет-странице Музеја. Додатни едукативни програ- 
ми, поред наведених постојећих, могли би се одвијати на оба нивоа, као и у просторијама Музеја које тек треба да се адаптирају за употребу.

Оно што Музеј савремене уметности Војводине не нуди посетиоцима ни током 2015. године је увид у изложбе Музеја пре 2012. године, као и приказ свих публикација Музеја, што би било од великог значаја с обзиром на то да Музеј нема сталну поставку и током привремених изложби се може видети само неко, или чак ниједно, дело из колекција Музеја. Само око две стотине од неколико хиљада предмета из збирки је приказано у онлајн колекцији на интернет-страници Музеја, док посетилац нема прилику да та дела види у реалном простору када дође до изложбених просторија Музеја, осим током изложби аквизиција (откупа и поклона) које се организују, у просеку, једном у пет година. Са новим визуелним идентитетом Музеја у релацији са новим просторима за делатности које ће добити реализацијом преуређења сутеренског дела, изостављена је презентација дотадашњих активности, то јест увид у активности Музеја до тада. Посетиоцима се у згради не нуди ништа осим текућих програма и могућности да прелистају/ купе одабране каталоге изложби.

Приказ ових сегмената Музеја у самој згради не би захтевао много простора и они би се могли приказати у близини велике изложбене сале, или у оквиру едукативног центра који би се реализовао у сутеренском делу Музеја. С обзиром на то да МСУВ нема сталну поставку, едукативни центар би унутар зграде пружао посетиоцима могућност да, поред понуђеног програма, имају увид у виртуелну и материјалну документацију Музеја, која укључује све публикације од настанка Музеја, одабран материјал са свих претходних изложби, приказ колекције кроз аудио-видео прилоге, као и могућност коришћења богате специјализоване библиотеке о савременој уметности региона која је сада недоступна посетиоцима. Едукативни центар би био намењен како студентима и стручњацима у области и блиским дисциплинама тако и најширем броју грађана, као и туристима који први пут долазе у град и који желе да сазнају мало више о савременој уметности Војводине од онога што се нуди у оквиру текуће изложбе. Аудио-прилози би били од посебног значаја за слепе и слабовиде, за које ретко који музеји имају специјализоване програме.

Са лансирањем новог сајта у оквиру новог (визуелног) идентитета МУСВ, могла би се приредити електронска едиција која би се фокусирала на презентацију теза и дисертација младих магистара и докторанада у сфери уметности и науке о уметности, као и на научне зборнике, чиме би се понудио богатији и доступнији садржај за едукацију о савременој уметности. Осим тога, Музеј савремене уметности Војводине би у домену организације 
и уступања простора, а можда и у домену продукције, могао да изађе у сусрет кандидатима за звање доктора на уметничким и интердисциплинарним студијама које захтевају реализацију (излагање) рада, као и текстуалну одбрану истог у форми тезе или дисертације. Сличну форму презентације захтевају и одбране студената постдипломских студија одређених факултета у Новом Саду, и оне би се могле презентовати у просторима Музеја, иако Музеј као институција није усмерена на промовисање младих уметника и стручњака.

Сама зграда Музеја савремене уметности Војводине је веома неупадљива и удаљена од линије улице, тако да дизајнирање андроид/веб апликација које упућују на то како доћи до Музеја не би била сувишна стратегија, а за њихову реализацију би се могао расписати конкурс који би се спровео за студенте факултета у струци. Током 2014. године био је расписан архитектонски конкурс којим би се добили нови простори у сутеренском делу платоа испред зграде, али којим би се и преуредио сам плато. Одабрано решење као једино средство скретања пажње на зграду предвиђа фонтану са клупама распоређеним око ње, које ће привући пролазнике да скрену у тај део, али не најављује садржај Музеја. Одабрано решење такође не предвиђа надземни садржај испред зграде (чак ни привременог, демонтажног типа) који би више пажње публике привлачио него подземни садржаји. Осим тога, подземни садржаји захтевају више времена да им се приступи и чине главни улаз у главне изложбене просторе још удаљенијим.

Насупрот томе, другопласирани рад на конкурсу (пројектни биро „Бекамент д.о.о.“, Београд) предлаже постављање (реплике) скулптуре Џефа Кунса која је направљена од нерђајућег челика, а представља увећану фигуру пса коју кловнови праве од балона. Ова металик зелена скулптура визуелно упадљиво наглашава садржај Музеја наспрам сиве бетонске фасаде. Уместо те скулптуре, могла би се поставити нека скулптура из колекције Музеја која је предвиђена да стоји на отвореном, како би најавила садржај зграде, у истој мери у којој то раде поједини експонати збирке Одељења за новију историју Музеја Војводине, које је у истој згради. Оваква стратегија би пролазнике из прве руке информисала о томе да је на том месту Музеј савремене уметности. Динамични лед екран/табла на којој се смењују светлосна обавештења такође је решење којем прибегавају музеји савремене уметности, попут оног у Загребу. Помоћу тих треперећих обавештења која привалаче пажњу пролазника, посетиоци пре него што уђу у зграду имају одмах информацију о дешавањима у њој. У случају МСУВ, то би такође било место информисања о Музеју у најужем смислу, тако да посетиоци могу да одлуче да ли ће прво у централну зграду где је главни програм или 
у подземне просторије где се одвијају споредни програми и где је едукативни центар.

У оквиру постојећих изложбених просторија Музеја, мали број вођења је био реализован у вези са архитектуром саме зграде и генерално о периоду у којем је изграђена, а она је при томе заштићена као споменик културе. Ова вођења су била за студенте архитектуре, од стране кустоскиње за архитектуру и у сарадњи са професорима историје модерне архитектуре и урбанизма. Поред њих, могла би се организовати и вођења за шири круг публике која би била значајна за едукацију о савременим приступима архитектури модернизма, јер би се у оквиру њих могло говорити и о другим објектима у граду изграђеним у том периоду. Њих не би морали да организују само кустоси Музеја, него би она могла бити реализована у сарадњи удружења за очување архитектуре модернизма и педагошке службе.

\section{6. ЗАКЉУЧАК}

Садашња политика МСУВ више је оријентисана на приказ нових продукција - које најчешће нису продуциране од стране самог Музеја - него на презентацију музејског фонда. Велики акценат ставља се на присуство уметника, поготово када су инострани пројекти у питању, те су у року од годину дана гостовали уметници и кустоси са Тајвана, из Бремена, из Француске, Словеније, Босне и Херцеговине. Како су кустоси сконцентрисани на рад са уметницима и на представљање актуелних уметника из Србије/ Војводине у иностранству, остаје запостављен рад са публиком музеја. Од како је откупљен видео-рад Марине Абрамовић за милион динара, услед висине цене откупа, поставила су се питања о презентацији таквих откупљених радова и колекције уопште. Тек се пројектом који се реализује у оквиру програма Креативна Европа, подржаном од стране Европске комисије, предвиђа рад на презентацији колекција, где ће сваки кустос у форми видео-снимака, публикација и студијских путовања презентовати колекцију Музеја. Године 2016, када је 50 година од оснивања Музеја савремене уметности Војводине, колекције ће бити поново у фокусу, али остаје питање да ли ће кустоси колекција радити са публиком свих узраста како би те колекције биле на адекватан начин представљене и приближене широј јавности.

Због отворености Музеја најширој публици, креирање едукативног центра и запошљавање сталног водича или кустоса-педагога постављају 
се као императиви за ефикасно функционисање Музеја. На тај начин би Музеј без сталне поставке нудио увид у све претходне пројекте које је реализовао, као и оне пројекте које су релизовани у сродним институцијама у Војводини, приказујући савремену уметност Војводине у најширем издању. Запошљавањем кустоса-педагога створила би се програмска и радна политика институције која би за сваки пројекат нудила едукативне програме истог типа - вођења, радионице, презентације и дискусије - независно од раположивости средстава да се привремено ангажује водич. Запошљавање кустоса-педагога значило би и имати запосленог у Музеју који је у току са креирањем годишњих изложбених програма и који може у сагласности са осталим кустосима да креира едукативне програме и обезбеди буџет за њихову реализацију. Осим тога, кустос-педагог би за сваку најаву предстојећих изложби у сарадњи са кустосом који организује изложбу и службом за односе са јавношћу креирао посебне најаве истих изложби за различите циљне групе - једну најаву за основношколске установе, једну за средњошколске, једну за факултете, једну за струковне колективе и удружења итд. На тај начин би се обезбедила заинтересованост код публике и позитиван одзив посетилаца.

Алтернатива овој могућности је да се ради са постојећим капацитетима, што би значило да сваки кустос буде дежуран током изложбе коју је организовао и да као најстручније лице буде стално на услузи посетиоцима током трајања изложбе, а не да у том периоду радно време проводи у канцеларији као током осталих месеци у години. Досадашња пракса МСУВ у вези са контактом кустоса и посетилаца сводила се у просеку на једно или два заказана јавна вођења током целог трајања изложби које је око 3-4 недеље, што је мање него што се примењује и у музејима „разумљивијег“ фонда, тј. фонда који је ближи материји која се учи у основним и средњим школама. Осмишљавањем и активирањем педагошког, то јест едукативног и методичког сегмента МСУВ, овај музеј би постао интегрални део градског културног живота за све узрасте.

\section{7. ЗАВРШНЕ НАПОМЕНЕ}

Анализа коју представља рад завршена је 2015. године. Ауторка се овом приликом захваљује Слађани Велендечић, из Одељења за педагошки рад и односе са јавношћу Музеја Војводине, на указаној помоћи при детаљнијем упознавању са дисциплином музејске педагогије. 


\section{ЛИТЕРАТУРА}

Balmas, P. (2010). „Mapa muzeja savremene umetnosti“, u Muzeji koji privlače pažnju, ur. A. Bonito Oliva (Beograd: Clio): 183-264.

Frejzer, A. (2013). „Nije li ovo divno mesto? (Obilazak Gugenhajmovog muzeja u Bilbau)“, u Savremena umetnost i muzej: kritika političke ekonomije umetnosti, ur. J. Stojanović (Beograd: Muzej savremene umetnosti): 209-241.

Јовановић, М. (1994). Музеологија и заштита споменика културе. Београд: Филозофски факултет. [Jovanović, М. (1994). Muzeologija i zaštita spomenika kulture. Beograd: Filozofski fakultet.]

Лукач, А. (2012). „Седам питања савремене музеологије“. ІСОМ Србија 2: 12-18. [Lukač, A. (2012). „Sedam pitanja savremene muzeologije“. ICOM Srbija 2: 12-18.]

Панић, А. (2011). „Уметност бављења публиком“. ІСОМ Србија 1 (тема броја: Едукаиија у музејима): 31-33. [Panić, A. (2011). „Umetnost bavljenja publikom“. ICOM Srbija 1 (tema broja: Edukacija u muzejima): 31-33.]

Поповић, У. (2011). „Учење унутар интердисциплинарног контекста: Витни музеј америчке уметности у Њујорку - одељење едукације“. ICOM Србија 1: 21-22. [Popović, U. (2011). „Učenje unutar interdisciplinarnog konteksta: Vitni muzej američke umetnosti u Njujorku - odeljenje edukacije“. ICOM Srbija 1:21-22.]

Пул, Н. (2012). „Релевантност, агенција, проток”. ICОМ Србија, 2: 6-9. [Pul, N. (2012). ,Relevantnost, agencija, protok”. ICOM Srbija, 2: 6-9.]

Smit, T. (2013). „Bilbao efekat: kultura kao industrija“, u Savremena umetnost $i$ muzej: kritika političke ekonomije umetnosti, ur. J. Stojanović (Beograd: Muzej savremene umetnosti): 245-269.

Stojanović, J. (2013). Savremena umetnost i muzej: kritika političke ekonomije umetnosti. Beograd: Muzej savremene umetnosti.

Subotić, I. (2005). „Stvoriti i voleti publiku“, u Muzej i publika, ur. K. Žilber (Beograd: Clio, Muzejsko društvo Srbije): 5-32. 


\title{
Sonja Jankov \\ Museum of Contemporary Art of Vojvodina \\ Novi Sad \\ jankovsonja@gmail.com
}

\section{EDUCATIONAL POTENTIONAL OF THE MUSEUM OF CONTEMPORARY ART VOJVODINA}

\begin{abstract}
Summary
The paper focuses on educational aspect of museums of contemporary art as one of their most important aspects. Giving the overview of the value these institutions have for contemporary cultural and economic development of the cities they are in, the paper further examines the position of contemporary art for life of citizens worldwide. Since it is not part of primary and secondary school programmes, contemporary art has educational importance in terms of socialisation and learning about society we live in. It can be approachable both to children under three and senior citizens through special workshops and curatorial guidance in museums dedicated for preservation and promotion of contemporary art. These museums have became the centres of contemporary art in the very meaning of the word, to the extent that the new buildings where they are placed are the most representative artefacts of contemporary art. The paper further analyses work with visitors in Museum of Contemporary Art of Vojvodina in Novi Sad (Serbia) in period 2012 to 2015, giving the specific characteristics of this Museum, such as the absence of permanent exhibition, focus on new productions that are only presented in the Museum and rare inclusion of any from several thousand artworks from the Museum's collections. Since collections are not presented in the Museum's space, and on the web site of the Museum one can see only fewer than 200 reproductions from the collections, the paper argues for complete documentation of previous events and larger online collection that would be also available to visitors within the very building of the Museum. Since MCAV today has the leading role in presentation of contemporary art in Serbia, it must work on its relation to visitors, at least because it is public, state institution that exists because of the visitors. The paper concludes that, if unable to exhibit and digitalize more artworks from the collections, the curators must be always present and ready to serve the visitors, since the Museum has no employed guide, visitors' assistant or curator.
\end{abstract}

Key words: museum, contemporary art, visitors, MCAV.

Примљено: 4. 3. 2016. Прихваћено: 5. 4. 2016 